\title{
Interleukin-2 and Interleukin-2 Receptor Expression in Human Corticotrophic Adenoma and Murine Pituitary Cell Cultures
}

\author{
Eduardo Arzt, Gertraud Stelzer, Ulrich Renner, Manfred Lange, * O. Albrecht Müller, ${ }^{\star}$ and Günter K. Stalla \\ Max-Planck-Institute of Psychiatry, Clinical Institute, 8000 Munich 40; and Departments of *Neurosurgery \\ and ${ }^{\ddagger}$ Medicine, University of Munich, 8000 Munich 2, Federal Republic of Germany
}

\begin{abstract}
The production of IL-1 and IL-6 by pituitary cells has recently been demonstrated. In this study we investigated the expression of IL-2 and its receptor (IL-2R) by pituitary cells of different species. In Northern blots, a single hybridizing band of 1 $\mathbf{k b}$, identical to that in normal stimulated lymphocytes, was obtained with specific IL-2 probes. In the mouse AT-20 pituitary tumor cell line, IL-2 mRNA expression was detected after stimulation with corticotropin-releasing hormone or phorbol myristate acetate. In human corticotrophic adenoma cells, basal IL-2 mRNA expression as well as IL-2 secretion were further stimulated by phorbol myristate acetate. Both adenoma and AtT-20 cells showed detectable amounts of IL-2R mRNA and by immunofluorescence, IL-2R membrane expression. In addition, dual immunofluorescence studies in rat anterior pituitary cells demonstrated colocalization of IL-2R with ACTHpositive cells and other cell types expressing the receptor. In addition to the action of lymphocyte-produced IL-2, this cytokine may have a paracrine or autocrine regulatory role within the pituitary. It remains to be established whether IL-2 production occurs in the normal pituitary or is intrinsic to the process of tumor development of these cells. IL-2 may be involved in the growth control of pituitary cells. (J. Clin. Invest. 1992. 90:1944-1951.) Key words: neuroimmunology • cytokines • hypothalamo-pituitary-adrenal axis $\bullet$ anterior pituitary $\bullet$ interleukin-2 pathway
\end{abstract}

\section{Introduction}

It has been described that the central nervous system is a target or source of lymphokines (1-5). Receptors for IL-1 and IL-2 have been found in the central nervous system, mainly localized in the hippocampus (5-8). IL-1 $\beta$ immunoreactive fibers were found in the hypothalamus, innervating key endocrine cell groups (9). Rat medial basal hypothalamic cultures release IL-6 and express its mRNA (10). Recently, IL-1 and IL-6 pro-

Portions of this work were presented at the 11 th Meeting of the European Federation of Immunological Societies, Helsinki, Finland, 9-12 June 1991, and at the 5th Meeting of the European Neuroendocrine Association, Budapest, Hungary, 25-28 August 1991, and were published in abstract form (1991. J. Endocrinol. Invest. 14 [Suppl. 46]:188).

Address reprint requests to Dr. Eduardo Arzt, Max-Planck-Institute of Psychiatry, Clinical Institute, Kraepelinstrasse 10, 8000 Munich 40, FRG.

Received for publication 10 September 1991 and in revised form 12 May 1992.

J. Clin. Invest.

(c) The American Society for Clinical Investigation, Inc. $0021-9738 / 92 / 11 / 1944 / 08 \quad \$ 2.00$

Volume 90, November 1992, 1944-1951 duction by pituitary cells has been demonstrated. IL- $1 \beta$ immunoreactive material and mRNA was found in rat pituitaries and shown to increase after bacterial lipopolysaccharide treatment of the rats (11). IL-1 receptors were characterized in mouse pituitary cells and AtT-20 corticotrophs (12). IL-6 production and stimulation by IL-1 has been demonstrated in rat anterior pituitary cells (13-17). The expression of IL-6 mRNA in rat anterior pituitary (10) and corticotrophic adenoma (18) cell cultures and the release of IL- 6 from human pituitary adenoma cultures (19) have also been reported. The stimulatory action of IL-1 on the hypothalamo-pituitary-adrenal axis has been extensively studied. Despite discrepancies in the literature, it seems to act at the hypothalamic, pituitary, and adrenal levels to induce corticotropin-releasing hormone ( $\mathrm{CRH}),{ }^{1}$ corticotropin (ACTH), and cortisol production (20, reviewed in 21 and 22). Similar results were found for IL-6 (21 and 22). It was postulated, therefore, that IL- 1 and IL- 6 may be involved in the paracrine or autocrine regulation of pituitary function $(11,14)$. IL-2 also acts on the hypothalamo-pituitary-adrenal axis. It has been shown to enhance proopiomelanocortin gene expression $(23,24)$ and to induce ACTH release in the AtT-20 murine cell line and in rat anterior pituitary cell cultures (2527 ). In the latter, it also induces the release of other hormones, such as prolactin $(25,28)$. When administered to human cancer patients, it increases $\beta$-endorphin, ACTH, and cortisol levels $(29,30)$. Further, it stimulates $\beta$-endorphin and ACTH levels in allografted (31) and normal (32) rats, respectively. Several reports, however, failed to find effects of IL-2 in these systems, though more recently, a report suggests that this may be related to species-specific IL-2 forms (32). Here it was shown that while rat IL-2 enhances ACTH release in rats, human (hu) IL-2 has no effect on rat ACTH levels (32). As IL-1 and IL- 6 are localized in pituitary cells, and as a protein related to the $\alpha$-chain of the IL-2 receptor (IL-2R) has been shown in these cells (27), we have investigated whether IL-2 and its receptor could be synthesized by pituitary cells.

\section{Methods}

Patients. Nine patients (eight women and one man) aged 16-55 yr, with typical features of chronic hypercortisolism, including facial and truncal obesity and hypertension, were studied. Of these patients, eight had hypogonadism and two had hypothyroidism. The presence of a corticotrophic adenoma was suspected by endocrine evaluation. Mean plasma cortisol concentrations, derived from five measurements at 4-5-h intervals within a 24-h period, were determined in the immediate preoperative period and showed a canceled dhurnal rhythm of secretion. The range of mean plasma cortisol concentrations was 486-1,242 $\mathrm{nmol} /$ liter (normal: $250-650 \mathrm{nmol} /$ liter). A low dose dexamethasone ( $2 \mathrm{mg}$ ) suppression test failed to produce suppression of cortisol secre-

1. Abbreviations used in this paper: $\mathrm{CRH}$, corticotropin-releasing hormone; hu, human; IL-2R, IL-2 receptor; POMC, proopiomelanocortin. 
tion. In the insulin-hypoglycemia test $(0.15 \mathrm{IU} / \mathrm{kg}$ body wt), patients did not show an appropriate response of cortisol secretion. The range of basal plasma ACTH concentrations was $10-50$ pmol/liter (normal: 4-17 pmol/liter). All patients responded to a large dose of dexamethasone $(8 \mathrm{mg})$ with a significant decrease in plasma cortisol levels. In addition, every patient was subjected to a sinus-petrosus-inferior catheterization in combination with a CRH stimulation test for the determination of pituitary origin and localization of ACTH secretion. Radiological investigation consisted of a nuclear magnetic resonance scan. All patients were persistently cured after transsphenoidal microsurgery.

Tumors. After surgery the adenoma tissue was transported in the sterile culture medium described below. Routinely, the tumor transport medium and the conditioned medium obtained after $24 \mathrm{~h}$ of culture as described below, were assayed for all anterior pituitary hormones. The nine tumors were selected for these studies because they had no detectable levels of prolactin, luteinizing hormone, folliclestimulating hormone, growth hormone, and thyroid-stimulating hormone, in contrast to high ACTH levels ( $>2,000 \mathrm{pmol} /$ liter), in both transport and conditioned medium. In addition, in three of these nine cases, where enough material was present, immunocytochemical studies were performed, confirming that $>95 \%$ of the cells were corticotrophs.

Cell cultures. Unless stated, materials and reagents were from Flow Laboratories (Meckenheim, FRG), Seromed (Berlin, FRG), Gibco Laboratories (Karlsruhe, FRG), Falcon Labware (Heidelberg, FRG), and Nunc (Wiesbaden, FRG). Pituitary cell culture was performed as previously described $(33,34)$. In brief, for the preparation of human corticotrophic cells, the tissue was washed several times with preparation buffer ( $137 \mathrm{mM} \mathrm{NaCl}, 5 \mathrm{mM} \mathrm{KCl}, 0.7 \mathrm{mM} \mathrm{Na}_{2} \mathrm{HPO}_{4}, 10 \mathrm{mM}$ glucose, $15 \mathrm{mM}$ Hepes $\mathrm{pH}$ 7.3, antibiotics). Sliced fragments were dispersed mechanically and enzymatically in preparation buffer containing $4 \mathrm{~g}$ /liter collagenase (Cooper Biomedical, Inc., Malvern, PA), $10 \mathrm{mg} /$ liter DNAase II, $0.1 \mathrm{~g} /$ liter soybean trypsin inhibitor and 1 $\mathrm{g} /$ liter hyaluronidase. Cells were centrifuged and resuspended in culture medium (DME) containing 10\% FCS, $2.2 \mathrm{~g} /$ liter $\mathrm{NaHCO}_{3}, 10$ $\mathrm{mM}$ Hepes, $2 \mathrm{mM}$ glutamine, $10 \mathrm{ml} /$ liter nonessential amino acids, 10 $\mathrm{ml} /$ liter minimal essential medium vitamins, antibiotics, $5 \mathrm{mg} /$ liter insulin, $20 \mu \mathrm{g} /$ liter selenium, $5 \mathrm{mg} /$ liter transferrin, and $30 \mathrm{pM}$ triiodothyronine (Henning, Berlin, FRG), pH 7.3). Between 3 and $6 \times 10^{6}$ cells with a viability of at least $80 \%$ (acridine orange/ethidium bromide staining) were isolated, distributed $\left(2 \times 10^{5}\right.$ viable cells $\left./ \mathrm{ml}\right)$ to 24 -well culture plates or, for immunofluorescence studies, in slide flasks and incubated $\left(37^{\circ} \mathrm{C}, 5 \% \mathrm{CO}_{2}\right)$. Few cells could be isolated from each microadenoma, preventing many parallel experiments. For rat anterior pituitary cells, glands were obtained from male Sprague Dawley rats $(200-300 \mathrm{~g})$ within minutes of death by decapitation and were treated as described for adenomas. Both human and rat pituitary cells attached to the dishes within 48-72 $\mathrm{h}$ and were used 4-6 $\mathrm{d}$ after plating. The pituitary preparations were free of lymphocyte contamination as they were $<1 \%$ reactive by immunofluorescence with the following monoclonal antibodies (Dianova, Hamburg, FRG): CD2, CD4, CD8, CD14, CD19, and CD45 which define antigens on $T$ cells/NK cells, $T$ helper lymphocytes, $T$ cytotoxic/suppressor cells, monocytes/macrophages, B cells, and leukocytes (leukocyte common antigen), respectively. AtT-20, a mouse corticotrophic tumor cell line, was obtained from the American Type Culture Collection (ATCC, Rockville, MD) and cultured under the same conditions. For all experiments, using the three types of pituitary cultures, after washing the cells, medium was replaced by an experimental medium consisting of DME containing $0.5 \mathrm{~g} /$ liter BSA, $2.2 \mathrm{~g} /$ liter $\mathrm{NaHCO}_{3}, 30 \mu \mathrm{g} / \mathrm{ml}$ ascorbic acid, and 10 mM Hepes, pH 7.3, alone or with phorbol myristate acetate (PMA) (Sigma Chemical Co., St. Louis, MO) or hu CRH (Bachem, Bubendorf, Switzerland). PBMC from healthy donors, mouse and rat spleen cells, were cultured with PHA, $10 \mu \mathrm{g} / \mathrm{ml}$ (for PBMC) or Con A, 2.5 $\mu \mathrm{g} / \mathrm{ml}$ (for spleen cells) (Sigma Chemical Co.) as described $(35,36$ ). Mouse 3T3 fibroblasts were cultured identically to the AtT-20 cells.

RNA analysis. Unless stated, reagents were from Sigma Chemical Co., Boehringer Mannheim Gmb H (Mannheim, FRG), or Pharmacia Fine Chemicals (Uppsala, Sweden). Total RNA was isolated by the guanidine isothiocyanate followed by phenol-chloroform method (37). RNA extraction, electrophoresis, blotting, radiolabeling of probes, and hybridization were performed as described $(33,34)$. Briefly, 5-10 $\mu \mathrm{g}$ RNA was denatured with glyoxal, electrophoresed on a $1.2 \%$ agarose gel, and transferred overnight to a nylon membrane: $\mathrm{Hy}$ bond-N (Amersham International, Amersham, UK) or Nytran-N (Schleicher and Schuell, Dassel, FRG). Filters baked for $2 \mathrm{~h}$ at $80^{\circ} \mathrm{C}$ were prehybridized for $4 \mathrm{~h}$ at $60^{\circ} \mathrm{C}(50 \%$ formamide, $5 \times$ sodium chloride sodium phosphate EDTA buffer [SSPE], $5 \times$ Denhardt's solution, $0.1 \% \mathrm{SDS}, 100 \mu \mathrm{g} / \mathrm{ml}$ denatured salmon sperm DNA ) and then hybridized with the addition of the probe at the same temperature for $12 \mathrm{~h}$. Blots were washed at increasing salt and temperature stringency with a final wash of $30 \mathrm{~min}$ at $60^{\circ} \mathrm{C}$ in $0.1 \times$ standard saline citrate (SSC) containing $1 \%$ SDS. Dried filters were exposed to Kodak XAR5 film at $-70^{\circ} \mathrm{C}$ with intensifying screens for $6 \mathrm{~h}-4 \mathrm{~d}$. Single-stranded antisense RNA probes were synthesized using T3 RNA polymerase and $\left[\alpha-{ }^{32} \mathrm{P}\right]-$ UTP (Amersham International) to give a sp act of $2-5 \times 10^{7} \mathrm{cpm} / \mu \mathrm{g}$ by in vitro transcription (Stratagene Inc., La Jolla, CA) using the following templates: a mouse POMC 140-bp cDNA coding for $\beta$-endorphin (38) (a generous gift from Dr. J. L. Roberts, Fishberg Center in Neurobiology, Mount Sinai School of Medicine, New York) and a 240-bp hu IL-2 cDNA coding for the last 77 amino acid residues of the carboxyl-terminal end of hu IL-2 (39) (a generous gift from Dr. J. Wietzerbin, Unité 196 INSERM, Section de Biologie, Institut Curie, Paris, France) both subcloned into Bluescribe (Vector Cloning Systems, San Diego, CA) and linearized with BamHI and EcoRI, respectively. The following cDNA probes ( $\mathrm{sp}$ act, $2-4 \times 10^{8} \mathrm{cpm} / \mu \mathrm{g}$ ) labeled with a random-primed kit with $\left[\alpha-{ }^{32} \mathrm{P}\right] \mathrm{dCTP}$ (Amersham International) were used: a 0.3-kb PstI-HindIII fragment of mouse IL-2 cDNA (40) (a generous gift from Dr. Dormer, Institute for Experimental Hematology, GSF-Forschungszentrum für Umwelt und Gesundheit, Munich, FRG), a 0.38-kb AvalI fragment of mouse IL-2R cDNA (41) (a generous gift from Dr. J. Miller, National Institutes of Health, Bethesda, MD), a 0.42-kb PstI fragment of mouse IL-2R cDNA (42) (a generous gift from Dr. T. Honjo, Kyoto University, Kyoto, Japan), a 0.92-kb EcoRI fragment of hu IL-2R cDNA (43) obtained from the ATCC and a 6.6-kb EcoRI fragment of a 28s and part of the 18s mouse cDNA (a generous gift from Dr. I. Grummt, German Center for Cancer Research, Heidelberg, FRG). The size of the bands were estimated in several blots by comparison to a RNA ladder. The autoradiograms were scanned with a laser densitometer (Ultroscan II; LKB Instruments Inc., Uppsala, Sweden). The blots were reprobed after eluting the first probe with $5 \mathrm{mM}$ Tris $/ \mathrm{HCl}$ pH 8.0, 2 mM EDTA, $0.1 \times$ Denhardt's solution, at $65^{\circ} \mathrm{C}$ for $2 \mathrm{~h}$. After the previous signal was removed, confirmed by reexposure of the filter, the blots were prehybridized and hybridized following methods described above. Controls with both the 28s-18s and the POMC probes were performed in all the blots from adenoma and AtT-20 cells.

$I L-2$ and $I L-2 R$ determinations. Both IL-2 and IL-2R were determined by RIA and immunofluorescence respectively, as described ( 34 , 35 ). Only species-homologous antibodies were used for each cell system. The adenoma supernatants were stored at $-20^{\circ} \mathrm{C}$ until measurement by a RIA with anti-hu IL-2 antibody (Medgenix, Fleurius, Belgium). No interference or cross-reaction with the experimental medium, ACTH (up to $1 \mu \mathrm{g} / \mathrm{ml}$ ), IL-1 or IL-6 was observed. The detection limit for this assay was $0.5 \mathrm{IL}-2 \mathrm{U} / \mathrm{ml}$. For IL-2R studies, after fixing the cells in formaldehyde-acetone, the antibody at serial dilutions was added for $30 \mathrm{~min}$ at $37^{\circ} \mathrm{C}$. Cells were extensively washed with PBS alone and with PBS containing 1\% Triton. Microscopy was performed (magnification, 500) with a Zeiss III RS (Göttingen, FRG) microscope. For the human cells an FITC-conjugated monoclonal mouse antibody, anti-hu p55 (TAC) subunit of the receptor was used (Immunotech, Marseille, France). For the mouse cells, a monoclonal rat anti-mouse TAC first antibody (PC61 5.3) produced by the hybridoma cell line TIB 222 (ATCC) and a FITC-conjugated goat anti-rat second antibody (Dianova) were used. For the rat cells an FITC-conjugated monoclonal mouse anti-rat TAC antibody was used (OX39; Serotec, Blackthorn Bichester, UK). Species-specific negative control antibodies, matched for Ig subclass and obtained from the same manu- 
facturers, were used at equivalent concentrations. As positive controls, stimulated PBMC, mouse and rat spleen cells were used. For dual immunofluorescence, fixation and washing were performed in the same way. Cells were preabsorbed for $1 \mathrm{~h}$ with $10 \%$ normal goat serum and incubated overnight with a rabbit anti-ACTH antibody generated as described $(33,34)$. After washing, a rhodamine-conjugated goat antirabbit IgG second antibody (Dianova) was added for $1 \mathrm{~h}$ at $37^{\circ} \mathrm{C}$. Cells were washed and treated with the OX39 antibody. Dual immunofluorescence microscopy was performed (magnification, 400) with an Olympus IMT-2 ( Tokyo, Japan ) microscope. Soluble IL-2R was measured by an immunoenzymometric assay (Immunotech).

Statistics. Statistics were performed by analysis of variance in combination with the Scheffe's test. Data are shown as mean \pm standard deviation.

\section{Results}

IL-2 $m R N A$ detection in pituitary cells. A single band of $\sim 1$ $\mathrm{kb}$, identical to that obtained with PHA-stimulated PBMC, was detected when RNA from human corticotrophic adenoma cells, stimulated for $24 \mathrm{~h}$ with $\mathrm{CRH}$, was hybridized with hu IL-2 antisense RNA (Fig. $1 A$ ). Two bands of ribosomal RNA identical for both pituitary and lymphocyte preparations can be observed after reprobing with a $28 \mathrm{~s}-18 \mathrm{~s}$ cDNA (Fig. $1 \mathrm{~B}$ ).

The same single band was obtained when hybridizing RNA from mouse AtT-20 corticotrophs stimulated for $24 \mathrm{~h}$ with CRH or PMA, with a mouse IL- 2 cDNA (Fig. $2 A$ ). To assess the normal function of the cells and the specificity of the hybridization, the filter was reprobed with a POMC cRNA. The classical pattern resulted (44): basal POMC mRNA expression, further stimulated with CRH or PMA (Fig. $2 B$; note different exposure times in Fig. 2, $A$ and $B$ ).

Blots of RNA from mouse 3T3 fibroblasts, cultured as negative controls in the same way as the AtT-20 cells, were per-
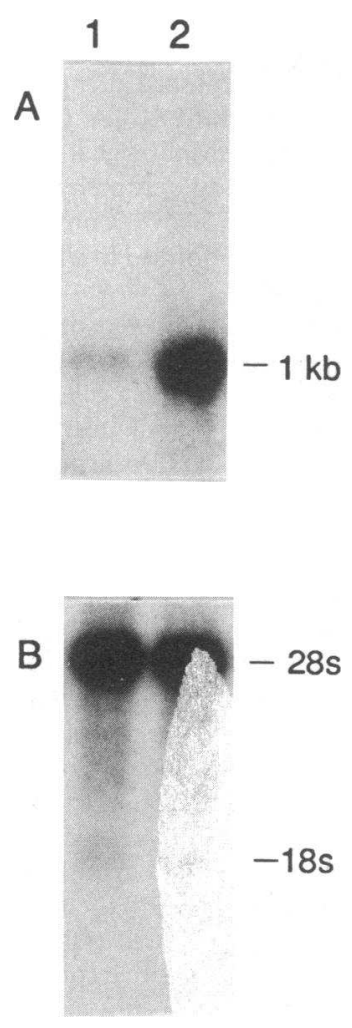
(A) Northern blot of RNA ( $8 \mu \mathrm{g}$ tota RNA per lane) extracted from stimulated human corticotrophic adenoma cells (lane 1) and PBMC (lane 2). Adenoma cells were stimulated for 24 $\mathrm{h}$ with CRH ( $10 \mathrm{nM})$ and PBMC for $6 \mathrm{~h}$ with PHA ( $10 \mu \mathrm{g} / \mathrm{ml})$. After hybridizing with a $0.24-\mathrm{kb}^{32} \mathrm{P}$-labeled hu IL-2 cRNA at $60^{\circ} \mathrm{C}$ and washing at high stringency, the autoradiograms were revealed after $4 \mathrm{~d}$ of exposure. A hybridizing band of identical size $(1 \mathrm{~kb})$ is present in both pituitary and lymphocytes. $(B)$ The same Northern blot as in $A$, but completely eluted of radioactivity and reprobed with a $28 \mathrm{~s}$ and part of $18 \mathrm{~s}^{32} \mathrm{P}$-labeled cDNA. The filter was hybridized and washed as in $A$ and exposed for $6 \mathrm{~h}$. The signal intensity of the 28s and 18s rRNA demonstrates that equal amounts of RNA were loaded in each lane. Differences between the $28 \mathrm{~s}$ and $18 \mathrm{~s}$ band intensities are because the cDNA encodes the complete $28 \mathrm{~s}$ and part of the 18s RNA. Similar results were obtained with six different adenoma cell preparations.
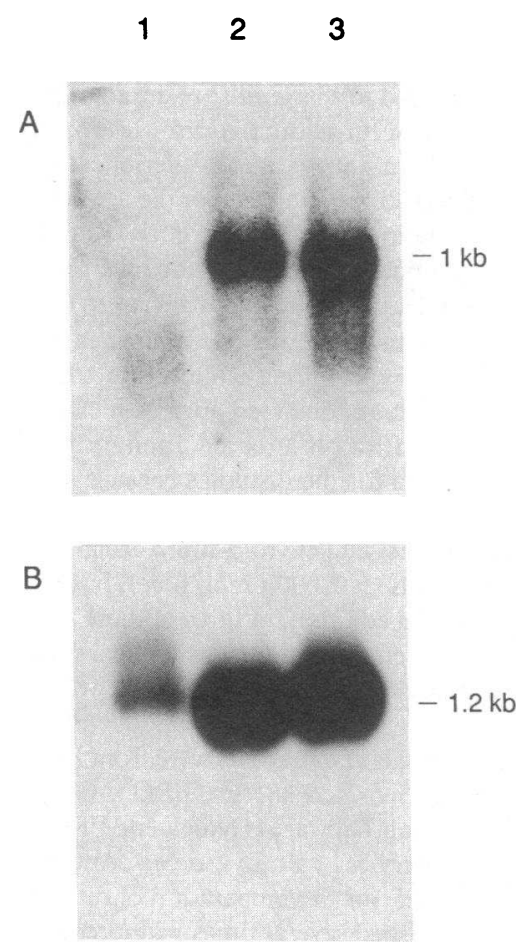

Figure 2. Detection of IL-2 mRNA in AtT-20 pituitary cells. $(A)$ Northern blot of RNA ( $10 \mu \mathrm{g}$ total RNA per lane) extracted from the corticotrophic mouse tumor cell line AtT-20. RNA was obtained after $24 \mathrm{~h}$ of culture in the following conditions: basal (lane 1), $10 \mathrm{nM}$ CRH (lane 2), or 10 nM PMA (lane 3). After hybridizing with a 0.3-kb ${ }^{32} \mathrm{P}$-labeled mouse IL-2 cDNA at $60^{\circ} \mathrm{C}$ and washing at high stringency, the autoradiograms were revealed after $4 \mathrm{~d}$ of exposure. A single hybridizing band of $1 \mathrm{~kb}$ is observed after stimulation. $(B)$ The same Northern blot as in $A$, but completely eluted

of radioactivity and reprobed with a $0.14-\mathrm{kb}^{32} \mathrm{P}$-labeled POMC cRNA. The filter was hybridized and washed as in $A$ and exposed for $6 \mathrm{~h}$. The classical signal pattern for POMC in these cells is observed demonstrating their normal function. Similar results were obtained with five different cell preparations.

formed and no signal was detected with the mouse IL-2 probe (Fig. $3 A$ ). The integrity of the RNA preparation was controlled with the $28 \mathrm{~s}-18 \mathrm{~s}$ probe (Fig. $3 B$ ).

In the adenoma cells, in contrast to the AtT-20 cells, after $24 \mathrm{~h}$ in experimental medium, there is a basal IL-2 mRNA expression that is not further stimulated with $\mathrm{CRH}$, but is signif-

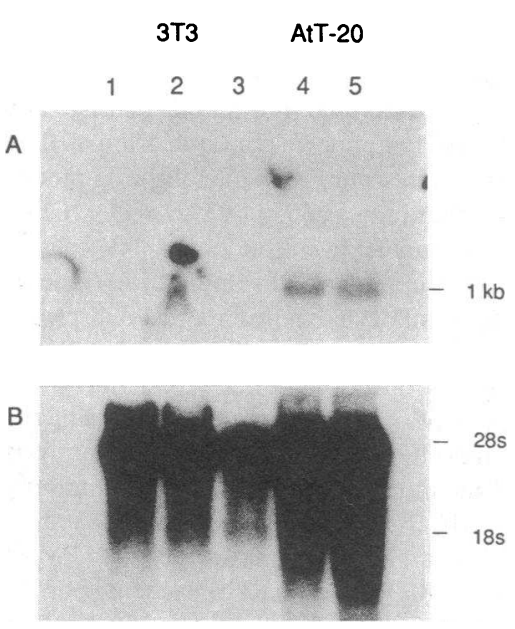

Figure 3. IL-2 mRNA in $3 \mathrm{~T} 3$ and $\mathrm{AtT}-20$ cells. $(A)$ Northern blot of RNA ( $10 \mu \mathrm{g}$ total RNA per lane) extracted from mouse $3 \mathrm{~T} 3$ fibroblasts and the corticotrophic mouse tumor cell line AtT-20. RNA was obtained after 24 $h$ of culture in the following conditions: basal (lane 1), 10 nM PMA (lanes 2 and 4 ), or 10 nM CRH (lanes 3 and 5). After hybridizing and washing as in Fig. 2 $A$ the autoradiograms were revealed after $2 \mathrm{~d}$ of exposure. $(B)$ The same Northern blot as in $A$, but completely eluted of radioactivity and reprobed with a $28 \mathrm{~s}$ and part of $18 \mathrm{~s}{ }^{32} \mathrm{P}$ labeled cDNA. The filter was hybridized and washed as in $A$ and exposed for $6 \mathrm{~h}$. Similar results were obtained with two different 3T3 cell preparations. 
icantly stimulated with PMA (Fig. 4, $A$ and $B$ ). CRH stimulation of IL-2 mRNA was only observed in one adenoma cell preparation.

The same respective patterns, with less intense signals, were obtained for both the human adenomas and AtT-20 cells after $6 \mathrm{~h}$ stimulation (data not shown).

IL-2 secretion by human corticotrophic adenoma cells. IL-2 secretion in the 24-h supernatants of adenoma cells cultured in experimental medium, showed a similar pattern as mRNA expression: basal secretion of IL-2 that is significantly stimulated by PMA (Table I). The maximum levels detected were 1-1.8 $\mathrm{U} / \mathrm{ml}$, about five times lower than those detected for $18 \mathrm{~h}$

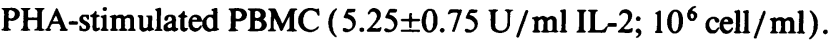
In two adenomas, one corresponding to CRH-stimulated IL-2 mRNA and the other where no RNA was extracted, CRH also

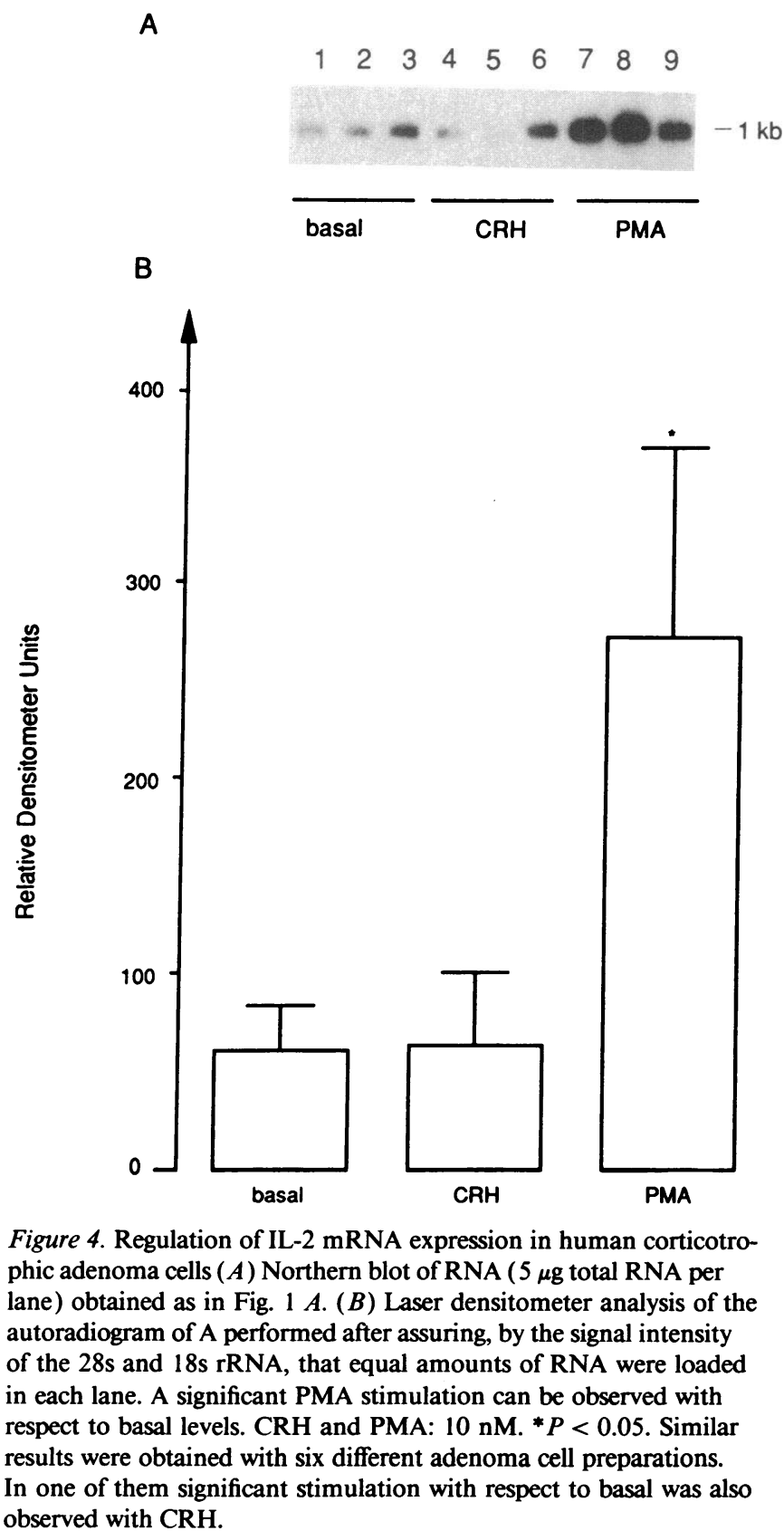

Table I. IL-2 Production by Human Corticotrophic Adenoma Cells

\begin{tabular}{ccc}
\hline Basal & CRH & PMA \\
\hline & $I L-2 U / m l$ & \\
$0.6 \pm 0.1$ & $0.5 \pm 0.1$ & $1.2 \pm 0.4^{*}$ \\
$0.6 \pm 0.1$ & $1.0 \pm 0.1^{*}$ & $1.2 \pm 0.3^{*}$ \\
$0.6 \pm 0.1$ & $1.0 \pm 0.2^{*}$ & $1.1 \pm 0.2^{*}$ \\
$0.9 \pm 0.1$ & $0.7 \pm 0.3$ & $1.1 \pm 0.1^{*}$ \\
$0.7 \pm 0.2$ & $<0.5$ & $1.8 \pm 0.1^{*}$ \\
& & \\
\hline
\end{tabular}

IL-2 production was measured by RIA in the 24-h supernatant of human corticotrophic adenoma cells cultured in experimental medium under the following conditions: basal, $10 \mathrm{nM}$ PMA or $10 \mathrm{nM}$ $\mathrm{CRH}$. Each line shows mean values \pm SD of one out of five different adenoma cell preparations in which each experimental condition was replicated in four wells. In each assay, controls consisting of experimental medium had no detectable levels of IL-2.

$P$ with respect to basal values: ${ }^{*} P<0.05 ; \quad{ }^{\ddagger} P<0.001$.

significantly stimulated IL-2 levels with respect to the basal condition (Table I).

$I L-2 R m R N A$ detection and membrane expression in pituitary cells. When hybridized with an $\alpha$ (p55) hu IL-2R cDNA, RNA from human adenoma cells after $6 \mathrm{~h}$ at both basal and stimulated conditions gave only the $3.5-\mathrm{kb}$ band, out of the two detected in PBMC (Fig. $5 \mathrm{~A}$ ). Similar results were obtained with an $\alpha$ (p55) mouse IL-2R cDNA in $6 \mathrm{~h}$ RNA preparations from AtT-20 cells, in which two bands of $4.5 \mathrm{~kb}$ and $2.2 \mathrm{~kb}$, that correspond to two bands out of four detected in Con Astimulated mouse spleen cells, are observed (Fig. $5 \mathrm{~B}$ ). In both pituitary cell types, PMA also stimulated IL-2R mRNA expression (data not shown).

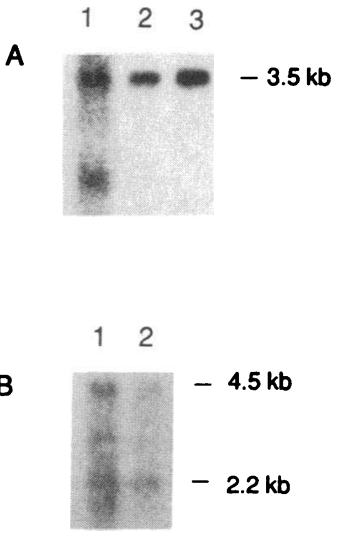

Figure 5. IL-2 receptor mRNA in human corticotrophic adenoma and AtT-20 cells. $(A)$ Northern blot of RNA ( $10 \mu \mathrm{g}$ total RNA per lane) extracted from PBMC stimulated for 18 $\mathrm{h}$ with PHA $(10 \mu \mathrm{g} / \mathrm{ml})$ (lane 1$)$ or human corticotrophic adenoma cells cultured for $6 \mathrm{~h}$ in the following conditions: basal (lane 2) or stimulated with CRH ( $10 \mathrm{nM}$ ) (lane 3). After hybridizing with a $0.92-\mathrm{kb}^{32} \mathrm{P}$-labeled hu IL-2R cDNA at $60^{\circ} \mathrm{C}$ and washing at high stringency, the autoradiograms were obtained after $2 \mathrm{~d}$ of exposure. A single hybridizing band of $\sim 3.5$ $k b$, identical to the PBMC larger band, is observed in the adenoma cells. Similar results were obtained in two different cell preparations. (B) Northern blot of RNA ( $10 \mu \mathrm{g}$ total RNA per lane) extracted from mouse spleen cells stimulated for $18 \mathrm{~h}$ with Con $\mathrm{A}(2.5 \mu \mathrm{g} / \mathrm{ml}$ ) (lane 1) or the mouse corticotrophic tumor cell line AtT-20 stimulated for $6 \mathrm{~h}$ with CRH ( $10 \mathrm{nM}$ ) (lane 2). After hybridizing with a 0.42-kb ${ }^{32} \mathrm{P}$-labeled mouse IL-2R cDNA at $60^{\circ} \mathrm{C}$ and washing at high stringency, the autoradiograms were obtained after $2 \mathrm{~d}$ of exposure. Two bands of 4.5 and $2.2 \mathrm{~kb}$, identical to that present in the mouse spleen cells, are observed in the AtT-20 cells. Similar results were obtained in four different cell preparations, in which basal expression was observed, and also with the use of another mouse IL-2 R cDNA, a 0.38-kb ${ }^{32} \mathrm{P}$-labeled fragment. 
Immunofluorescence studies, performed in both the adenoma and the AtT-20 cells with human and mouse monoclonal antibodies, respectively, show that pituitary cells express the receptor on the membrane (Fig. 6). For all experiments, over the whole slide area, positive cells were $\sim 10 \%$ under basal conditions and $\sim 40 \%$ under stimulation. In both cell types, there were no distinct differences in the extent of IL-2R positive cells after CRH or PMA stimulation.

To complement the study, IL-2R expression on normal rat pituitary cells was assessed (Fig. 7, $A$ and $B$ ). About $10-20 \%$ of the basal or CRH-stimulated cells and $50 \%$ of the PMA-stimulated cells, none of them fibroblasts, were positive for the IL-2R antibody. Dual immunofluorescence showed co-localization of the IL-2R with ACTH-positive cells and additional cells expressing the receptor (Fig. 7, $C-F$ ).

Using an antibody of the same isotype as the corresponding anti-IL-2R antibody $100 \%$ negative cells were observed for all the conditions, confirming the specificity of immunostaining. In addition, negative immunostaining was observed when second antibodies were added without previous addition of the primary antibody.
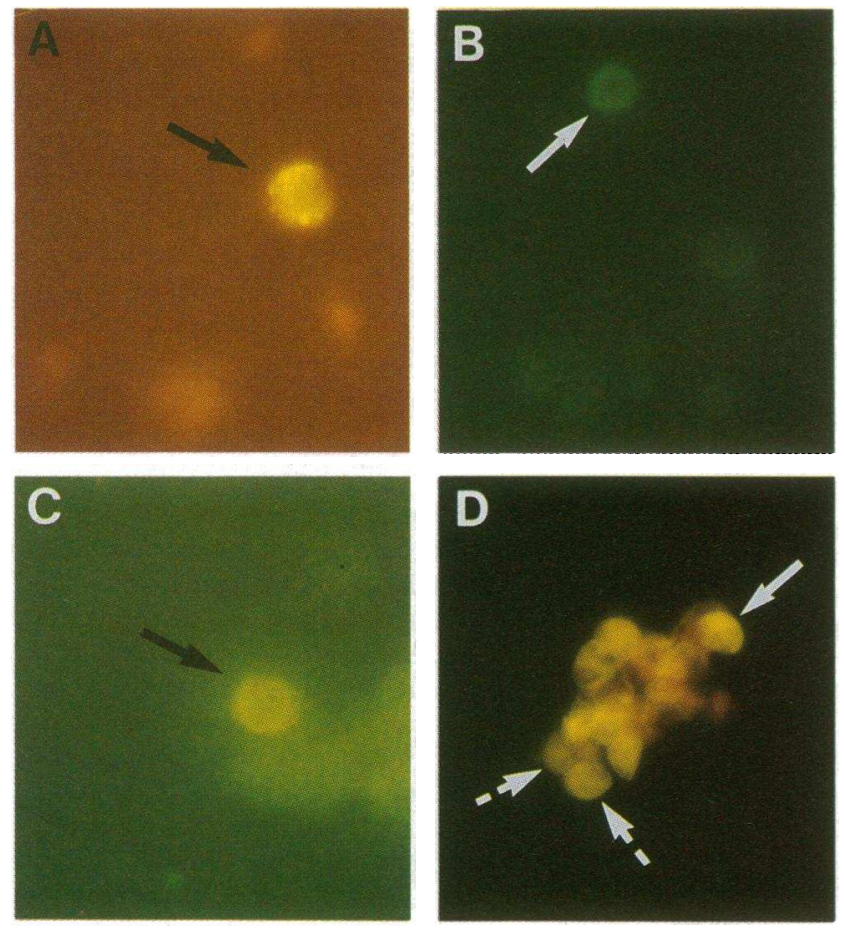

Figure 6. Membrane expression of IL-2 receptor in AtT-20 and human corticotrophic adenoma cells. Immunofluorescence photographs showing the presence of IL-2R-positive cells in human adenoma corticotrophic cells $(A)$ and AtT-20 cells $(B, C$, and $D)$. A specific antihuman TAC IL-2R (p55 subunit) FITC-conjugated monoclonal antibody was used diluted 1:100 $(A)$. For indirect immunofluorescence on the mouse cells, a monoclonal rat anti-mouse TAC antibody (PC61 5.3), produced by the hybridoma cell line TIB 222, was used $(1: 100)$ as first antibody and an FITC-conjugated goat anti-rat as second antibody. Cells were stained after $24 \mathrm{~h}$ of culture at basal condition $(B)$ or stimulation with $10 \mathrm{nM} \mathrm{CRH}(A, D)$ or $10 \mathrm{nM}$ PMA (C). Positive (arrows) and negative cells can be observed. Although differentiation between positive and negative cells is more difficult to observe due to the superposition of cells in the typical cluster conformation of AtT- 20 cultures, positive cells are present that can be distinguished from negative cells (broken arrows) $(D)$.
In the 24-h supernatants of the adenoma cells, soluble IL$2 \mathrm{R}$ was not detectable.

\section{Discussion}

IL-2 is a potent immunoregulatory cytokine critically involved in $\mathrm{T}$ cell activation. Its biological effects are mediated by specific receptors on target cells. Both IL-2 and IL-2R have been biochemically characterized and molecularly cloned and their interaction has been shown to be essential for the development of a normal immune response $(45,46)$. Neither their production nor their action seems to be confined to the immune cells since they have been detected in normal rat and human brains and brains of patients with neurological disease $(1,3,5)$. In the present report we describe, for the first time, the presence of IL-2 and IL-2R transcripts, as well as IL-2R membrane expression, in pituitary cells of different species: mouse AtT-20 corticotrophs and human corticotrophic adenoma cells. In the human adenoma cells IL-2 secretion was shown. Complementary to this, membrane expression of IL-2R in normal rat anterior pituitary cells and its colocalization with ACTH-secreting cells is described. The tumor origin of both corticotrophic cell types studied does not, however, allow us to be conclusive about the expression of the complete IL-2 pathway in normal pituitary cells. Moreover, we cannot exclude the possibility that other normal or tumor pituitary cell types also secrete IL-2. Although fibroblasts and endothelial cells were shown to produce IL-6 but not IL-2 $(47,48)$, we confirmed the absence of the IL-2 mRNA levels in mouse 3T3 fibroblasts, as a negative control, since primary pituitary cultures contain fibroblasts.

IL-2 at picomolar concentrations not only regulates ACTH, but also prolactin, luteinizing hormone, follicle-stimulating hormones, growth hormone, and thyroid-stimulating hormone secretion (25). It was concluded that the release pattern of anterior pituitary hormones is unique among the cytokines since it mimics almost completely the pattern of anterior pituitary response to stress (25). The presence of IL-2 receptors on the various cell types was considered to be the most likely explanation for the effects of IL-2 on the secretion of the various pituitary hormones (25). From our experiments, it is apparent that in addition to the corticotrophs, other pituitary cell types, that remain to be characterized, express the IL-2R.

Five distinct transcripts, with lengths from 1.7 to $4.7 \mathrm{~kb}$ (41) or four transcripts $(4.5,3.5,2.2$, and $1.5 \mathrm{~kb})(42)$ of IL-2R mRNA, in which the longest transcript predominates, were detected in IL-2R-positive T cells when the same mouse IL-2R cDNAs as used in this study were employed. In human cells, two transcripts of 3.5 and $1.5 \mathrm{~kb}$ were detected with the hu IL-2R cDNA (43). The different p55 IL-2R messages in the human are generated by the use of two principal transcription initiation sites, three different polyadenylation signals and alternative splicing of exon $4(46,49)$. Some of these processes seem to occur in the mouse (41). In our experiments, we detected only one ( $3.5 \mathrm{~kb})$ or two (4.5 and $2.2 \mathrm{~kb})$ transcripts in human and mouse pituitary cells, respectively. A predominant expression of the 3.5-kb transcript has been reported following interferon-gamma stimulation of monocytes (50), suboptimal stimulation of normal T cells with PHA or PMA, or after the induction of IL-2R in the Jurkat $T$ cell line by the tat gene of HTLV-II $(49,51)$. Further studies will be required to determine the molecular mechanisms responsible for the mRNA 

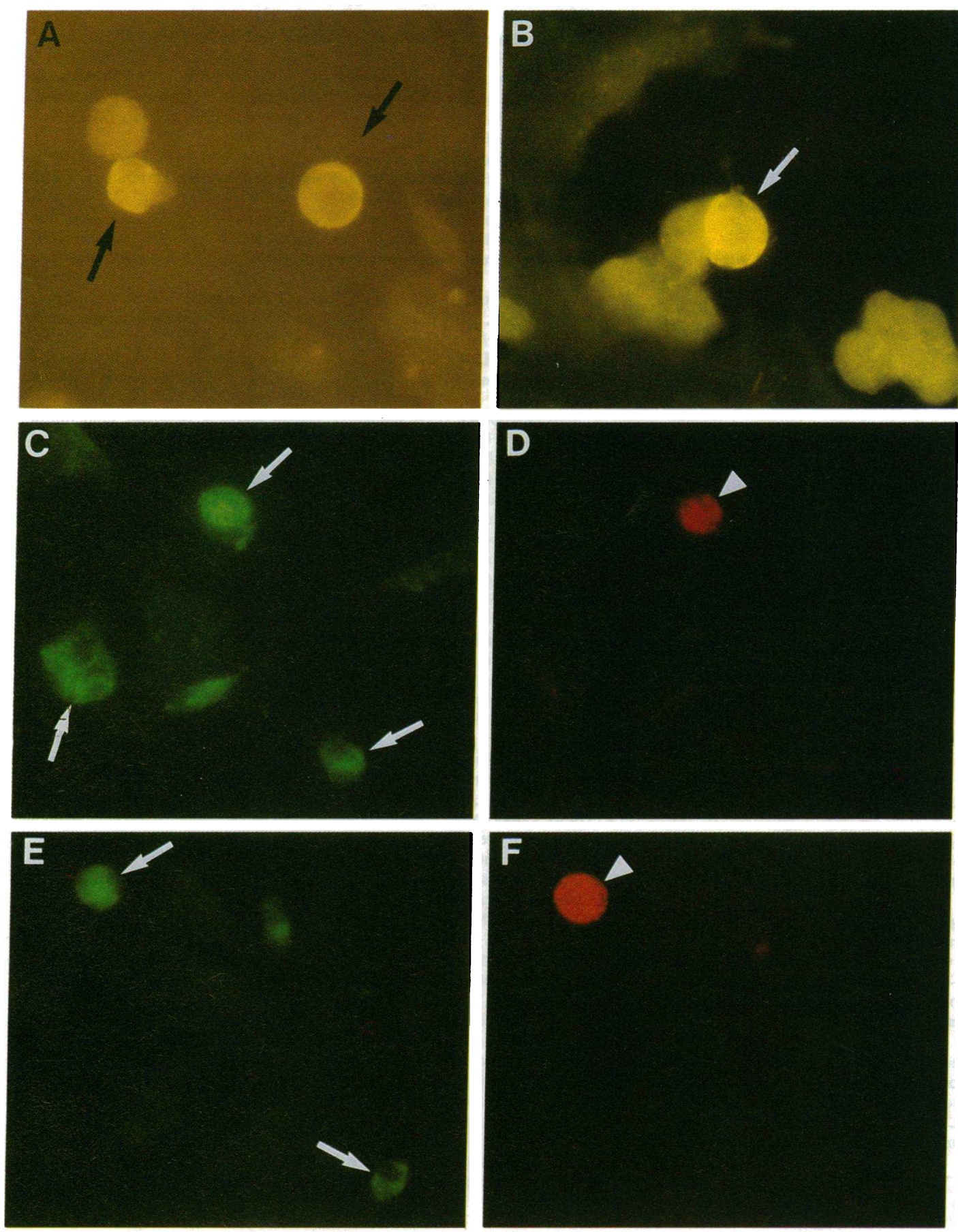

Figure 7. Membrane expression of IL-2 receptor in rat pituitary cells. $(A, B)$ Immunofluorescence photographs showing the presence of IL-2R positive cells in rat anterior pituitary cell cultures. A specific anti-rat TAC IL-2R (p55 subunit) FITC-conjugated monoclonal antibody was used diluted 1:100 $(A)$ or 1:20 $(B)$. Cells were stained after 24 $\mathrm{h}$ of stimulation with 10 nM PMA $(A)$ or $10 \mathrm{nM}$ CRH ( $B)$. Positive (arrows) and negative cells can be observed, including $B$, where a higher background is observed due to the higher antibody concentration. Fibroblasts present in the cultures were always negative. $(C-F)$

Dual immunofluorescence staining was performed in cells cultured for $24 \mathrm{~h}$ at basal conditions. After fixing, cells were preabsorbed for $1 \mathrm{~h}$ with $10 \%$ normal goat serum and incubated overnight with a rabbit anti-ACTH $(1: 5,000)$ first antibody. After washing, a rhodamine-conjugated goat anti-rabbit IgG second antibody was added. Cells were washed and then treated with the same FITC-conjugated anti-rat IL-2 antibody as in $A$ and $B$, diluted 1:50. Areas of the field were selected with positive cells (arrows) for the IL-2R ( $C$ and $E$ ) to facilitate the comparison with ACTH-positive cells ( partial arrows, $D$ and $F$ ).

Comparing the same cells ( $C$ with $D$ and $E$ with $F$ ) colocalization of the ACTH-positive cells with positive IL-2R staining can be observed, but also other IL-2R-positive cells.

species detected in the pituitary. This report is the first demonstration of IL-2R mRNA and membrane expression on pituitary cells and extends the previous description of an $\alpha$-chain of the IL-2R in these cells (27). The pharmacological characterization of the pituitary IL-2R will be necessary to further understand its biological function. In particular, the possible expression of the p70 $(\beta)$ subunit of IL-2R and its interaction with the p55 chain, must be established.

In the AtT-20 cells, IL- 2 mRNA was stimulated by CRH and PMA and in contrast to POMC gene expression, there were no detectable basal levels of IL-2 mRNA. In the adenoma cells, only the direct activation of protein kinase $C$ with PMA produced levels of both IL-2 mRNA and IL-2 that were significantly different from basal. However, in two different adenoma cultures, CRH stimulation via the adenylate cyclase system also significantly increased the secretion of IL-2. It is known that the CRH response in Cushing's patients may reveal hyperresponsiveness, normal responsiveness, and even unresponsiveness ( 52 ). In the nine patients of our study, the IL-2 production in response to $\mathrm{CRH}$ did not correlate with the POMC 
expression in response to CRH. Further information on the signals and second messengers involved in pituitary IL-2 synthesis should provide an understanding of whether the particular IL-2 responses to CRH have any pathophysiological implications.

In conclusion, corticotrophic pituitary cells express both IL-2 and p55 IL-2R genes. IL-2 is secreted and its receptor is expressed in the membrane of these cells. In normal rat cell cultures, besides the corticotrophs, other pituitary cell types express the receptor. Our first demonstration of IL-2R expression in the membrane of pituitary cells not only provides evidence of the pituitary site of action of lymphocyte-produced or exogeneously administered IL-2, but also, in view of the IL-2 production by the tumor cells, of a possible paracrine or autocrine role of this lymphokine. It remains to be established whether the IL-2 production occurs in the normal pituitary or if it is intrinsic to the process of tumor development of these cells. Considering its growth factor properties, IL-2 could be involved in the control of pituitary cell proliferation.

\section{Acknowledgments}

We wish to thank Joachim Sauer, Rosa Buric, Johanna Stalla, and Karin Lechner for their technical assistance and Dr. Christopher Newton for reviewing the manuscript for English usage. We acknowledge also the help of Regina Dressendörfer in the production and purification of the monoclonal antibody PC61 5.3.

This work was in part supported by a grant from the Deutsche Forschungsgemeinschaft (Sta 285/1-4).

\section{References}

1. Merrill, J. E. 1990. Interleukin-2 effects in the central nervous system. Ann. NY Acad. Sci. 594:188-199.

2. Liebermann, A. P., P. M. Pitha, H. S. Shin, and M. L. Shin. 1989. Production of tumor necrosis factor and other cytokines by astrocytes stimulated with lipopolysaccharide or a neurotropic virus. Proc. Natl. Acad. Sci. USA. 86:63486352.

3. Luber-Narod, J., and J. Rogers. 1988. Immune system associated antigens expressed by cells of the human central nervous system. Neurosci. Lett. 94:17-22.

4. Velasco, S., M. Tarlow, K. Olsen, J. W. Shay, G. H. McCracken, Jr., and P. D. Nisen. 1991. Temperature-dependent modulation of lipopolysaccharideinduced interleukin- $1 \beta$ and tumor necrosis factor $\alpha$ expression in cultured human astroglial cells by dexamethasone and indomethacin. J. Clin. Invest. 87:1674-1680.

5. Araujo, D. M., P. A. Lapchak, B. Collier, and R. Quirion. 1989. Localization of interleukin-2 immunoreactivity and interleukin-2 receptors in the rat brain: interaction with the cholinergic system. Brain Res. 498:257-266.

6. Farrar, W. L., P. L. Kilian, M. R. Ruff, J. M. Hill, and C. B. Pert. 1987. Visualization and characterization of interleukin 1 receptors in brain. $\mathrm{J}$. Immunol. 139:459-463.

7. Takao, T., D. E. Tracey, W. M. Mitchell, and E. B. De Souza. 1990. Interleukin-1 receptors in mouse brain: characterization and neuronal localization. Endocrinology. 127:3070-3078.

8. Cunningham, E. T., Jr., E. Wada, D. B. Carter, D. E. Tracey, J. F. Battey, and E. B. De Souza. 1991. Localization of interleukin-1 receptor messenger RNA in murine hippocampus. Endocrinology. 128:2666-2668.

9. Breder, C. D., C. A. Dinarello, and C. B. Saper. 1988. Interleukin-1 immunoreactive innervation of the human hypothalamus. Science (Wash. DC). 240:321-324.

10. Spangelo, B. L., A. M. Judd, R. M. MacLeod, D. W. Goodman, and P. C. Isakson. 1990. Endotoxin-induced release of interleukin-6 from rat medial basal hypothalami. Endocrinology. 127:1779-1785.

11. Koenig, J. I., K. Snow, B. D. Clark, R. Toni, J. G. Cannon, A. R. Shaw, C. A. Dinarello, S. Reichlin, S. L. Lee, and R. M. Lechan. 1990. Intrinsic pituitary interleukin- $\beta$ is induced by bacterial lipopolysaccharide. Endocrinology. 126:3053-3058.

12. De Souza, E. B., E. L. Webster, D. E. Grigoriadis, and D. E. Tracey. 1989. Corticotropin-releasing factor (CRF) and interleukin-1 (IL-1) receptors in the brain-pituitary-immune axis. Psychopharmacol. Bull. 25:299-305.
13. Vankelecom, H., P. Carmeliet, J. Van Damme, A. Billiau, and C. Denef. 1989. Production of Interleukin-6 by folliculo-stellate cells of the anterior pituitary gland in a histiotypic cell aggregate culture system. Neuroendocrinology. 49:102-106.

14. Spangelo, B. L., R. M. MacLeod, and P. C. Isakson. 1990. Production of interleukin-6 by anterior pituitary cells in vitro. Endocrinology. 126:582-586.

15. Spangelo, B. L., P. C. Isakson, and R. M. MacLeod. 1990. Production of interleukin- 6 by anterior pituitary cells is stimulated by increased intracellular adenosine 3',5'-monophosphate and vasoactive interstinal peptide. Endocrinology. 127:403-409.

16. Spangelo, B. L., A. M. Judd, P. C. Isakson, and R. M. MacLeod. 1991. Interleukin-1 stimulates interleukin-6 release from rat anterior pituitary cells in vitro. Endocrinology. 128:2685-2692.

17. Yamaguchi, M., N. Matsuzaki, K. Hirota, A. Miyake, and O. Tanizawa. 1990. Interleukin 6 possibly induced by interleukin $1 \beta$ in the pituitary gland stimulates the release of gonadotropins and prolactin. Acta Endocrinol. 122:201205.

18. Velkeniers, B., G. D'Haens, G. Smets, P. Vergani, L. Vanhaelst, and E. L. Hooghe-Peters. 1991. Expression of IL-6 mRNA in corticotroph cell adenomas. J. Endocrinol. Invest. (Suppl. 1) 14:31. (Abstr.).

19. Jones, T. H., S. Justice, A. Price, and K. Chapman. 1991. Interleukin-6 secreting human pituitary adenomas in vitro. J. Clin. Endocrinol. Metab. 73:207-209.

20. Besedovsky, H., A. Del Rey, E. Sorkin, and C. A. Dinarello. 1986. Immunoregulatory feedback between interleukin-1 and glucocorticoid hormones. Science (Wash. DC). 233:652-654.

21. Bateman, A., A. Singh, T. Kral, and S. Solomon. 1989. The immune-hypothalamic-pituitary-adrenal axis. Endocr. Rev. 10:92-112.

22. Hermus, A. R. M. M., and C. G. J. Sweep. 1990. Cytokines and the hypothalamic-pituitary-adrenal axis. J. Steroid Biochem. Mol. Biol. 37:867-871.

23. Brown, S. L., L. R. Smith, and J. E. Blalock. 1987. Interleukin 1 and Interleukin 2 enhance proopiomelanocortin gene expression in pituitary cells. $J$. Immunol. 139:3181-3183.

24. Low, K. G., T. V. Arevalo, and M. H. Melner. 1987. Interleukin-2 regulation of proopiomelanocortin gene expression in AtT-20 murine pituitary tumor cells. In Program and Abstracts of the 69th Annual Meeting of the Endocrine Society, Indianapolis, IN. 271. (Abstr.).

25. Karanth, S., and S. M. McCann. 1991. Anterior pituitary hormone control by interleukin 2. Proc. Natl. Acad. Sci. USA. 88:2961-2965.

26. Farrar, W. L. 1984. Endorphin modulation of lymphokine activity. In Opioid peptides in the periphery. F. Fraioli, A. Isidori, and M. Mazzetti, editors. Elsevier Science Publishers B.V., Amsterdam. 159-165.

27. Smith, L. R., S. L. Brown, and J. E. Blalock. 1989. Interleukin-2 induction of ACTH secretion: presence of an interleukin- 2 receptor $\alpha$-chain-like molecule on pituitary cells. J. Neuroimmunol. 21:249-254.

28. Karanth, S. 1991. The influence of dopamine (DA) on interleukin-2 induced release of prolactin (PRL), luteinizing hormone (LH) and follicle stimulating hormone (FSH) by the anterior pituitary. In Program and Abstracts of the 73rd Annual Meeting of The Endocrine Society, Washington, DC. 210. (Abstr.).

29. Lotze, M. T., L. W. Frana, S. O. Sharrow, R. J. Robb, and S. A. Rosenberg. 1985. In vivo administration of purified human interleukin 2 . I. Half-life and immunologic effects of the Jurkat cell line-derived IL-2. J. Immunol. 134:157-166.

30. Denicoff, K. D., T. M. Durkin, M. T. Lotze, P. E. Quinlan, C. L. Davis, S. J. Listwak, S. A. Rosenberg, and D. R. Rubinow. 1989. The neuroendocrine effects of interleukin-2 treatment. J. Clin. Endocrinol. \& Metab. 69:402-410.

31. Zakarian, S., M. S. Eleazar, and W. K. Silvers. 1989. Regulation of proopiomelanocortin biosynthesis and processing by transplantation immunity. $\mathrm{Na}$ ture (Lond.). 339:553-556.

32. Naito, Y., J. Fukata, T. Tominaga, Y. Masui, Y. Hirai, N. Murakami, S. Tamai, K. Mori, and H. Imura. 1989. Adrenocorticotropic hormone-releasing activities of interleukins in a homologous in vivo system. Biochem. Biophys. Res. Commun. 164:1262-1267.

33. Stalla, G. K., J. Stalla, M. Huber, J.-P. Loeffler, V. Höllt, K. von Werder, and O. A. Müller. 1988. Ketoconazole inhibits corticotropic cell function in vitro. Endocrinology. 122:618-623.

34. Stalla, G. K., J. Stalla, K. von Werder, O. A. Müller, R. Gerzer, V. Höllt, and K. H. Jakobs. 1989. Nitroimidazole derivatives inhibit anterior pituitary cell function apparently by a direct effect on the catalytic subunit of the adenylate cyclase holoenzyme. Endocrinology. 125:699-706.

35. Arzt, E. S., S. Fernández-Castelo, L. M. E. Finocchiaro, M. E. Criscuolo, A. Díaz, S. Finkielman, and V. E. Nahmod. 1988. Immunomodulation by indoleamines: serotonin and melatonin action on DNA and interferon- $\gamma$ synthesis by human peripheral blood mononuclear cells. J. Clin. Immunol. 8:513-519.

36. Labeur, M., V. E. Nahmod, S. Finkielman, and E. Arzt. 1991. Lesions of the medial septal nucleus produce a long-lasting inhibition of $\mathrm{T}$ lymphocyte proliferation. Neurosci. Lett. 125:129-132.

37. Chomczynski, P., and N. Sacchi. 1987. Single-step method of RNA isolation by acid guanidinium thiocyanate-phenol-chloroform extraction. Anal. Bio chem. 162:156-159. 
38. Roberts, J. L., P. H. Seeburg, J. Shine, E. Herbert, J. D. Baxter, and H. M. Goodman. 1979. Corticotropin and $\beta$-endorphin: construction and analysis of recombinant DNA complementary to mRNA for the common precursor. Proc. Natl. Acad. Sci. USA. 76:2153-2157.

39. Hu, J., C. Vaquero, S. Huet, A. Bernard, and G. Sterkers. 1987. Interleukin 2 up-regulates its own production. J. Immunol. 139:4109-4115.

40. Yokota, T., N. Arai, F. Lee, D. Rennick, T. Mosmann, and K.-I. Arai. 1985. Use of a cDNA expression vector for isolation of mouse interleukin 2 cDNA clones: expression of $\mathrm{T}$-cell growth-factor activity after transfection of monkey cells. Proc. Natl. Acad. Sci. USA. 82:68-72.

41. Miller, J., T. R. Malek, W. J. Leonard, W. C. Greene, E. M. Shevach, and R. N. Germain. 1985. Nucleotide sequence and expression of a mouse interleukin 2 receptor cDNA. J. Immunol. 134:4212-4217.

42. Shimuzu, A., S. Kondo, S. Takeda, J. Yodoi, N. Ishida, H. Sabe, H. Osawa, T. Diamantstein, T. Nikaido, and T. Honjo. 1985. Nucleotide sequence of mouse IL-2 receptor cDNA and its comparison with the human IL-2 receptor sequence. Nucleic Acids Res. 13:1505-1516.

43. Leonard, W. J., J. M. Depper, G. R. Crabtree, S. Rudikoff, J. Pumphrey, R. J. Robb, M. Krönke, P. B. Svetlik, N. J. Peffer, T. A. Waldmann, and W. C. Greene. 1984. Molecular cloning and expression of $\mathrm{cDNAs}$ for the human interleukin-2 receptor. Nature (Lond.). 311:626-631.

44. Affolter, H.-U., and T. Reisine. 1985. Corticotropin releasing factor increases proopiomelanocortin messenger RNA in mouse anterior pituitary tumor cells. J. Biol. Chem. 260:15477-15481.

45. Robb, R. J. 1984. Interleukin 2: the molecule and its function. Immunol. Today. 5:203-209.
46. Greene, W. C., and W. J. Leonard. 1986. The human interleukin-2 receptor. Annu. Rev. Immunol. 4:69-95.

47. Elias, J. A., G. Trinchieri, J. M. Beck, P. L. Simon, P. B. Seghal, L. T. May, and J. A. Kern. 1989. A synergistic interaction of IL-6 and IL-1 mediates the thymocyte-stimulating activity produced by recombinant IL-1-stimulated fibroblasts. J. Immunol. 142:509-514.

48. Sironi, M., F. Breviaro, P. Proserpio, A. Biondi, A. Vecchi, J. Van Damme, E. Dejana, and A. Mantovani. 1989. IL-1 stimulates IL-6 production in endothelial cells. J. Immunol. 142:549-553.

49. Leonard, W. J. 1986. Molecular and biochemical characterization of the human interleukin-2 receptor. In The human interleukin-2 receptor: normal and abnormal expression in $\mathrm{T}$ cells and in leukemias induced by the human $\mathrm{T}$-lymphotrophic retrovirusses (moderator: Greene, W. C.). Ann. Intern. Med. 105:560-572.

50. Rambaldi, A., D. C. Young, F. Herrmann, S. A. Cannistra, and J. D. Griffin. 1987. Interferon- $\gamma$ induces expression of the interleukin-2 receptor gene in human monocytes. Eur. J. Immunol. 17:153-156.

51. Greene, W. C., W. J. Leonard, Y. Wano, P. B. Svetlik, N. J. Peffer, J. G. Sodroski, C. A. Rosen, W. C. Goh, and W. A. Haseltine. 1986. Trans-activator gene of HTLV-II induces IL-2 receptor and IL-2 cellular gene expression. Science (Wash. DC). 232:877-880.

52. Pieters, G. F. F. M., A. R. M. M. Hermus, A. G. H. Smals, A. K. M. Bartelink, T. J. Benraad, and P. W. C. Kloppenborg. 1983. Responsiveness of the hypophyseal-adrenocortical axis to corticotropin-releasing factor in pituitary-dependent Cushing's disease. J. Clin. Endocrinol. \& Metab. 57:513-516. 